Tér és Társadalom 17. évf. 2003/1. 229-232. p.

Tér és Társadalom

XVII. évf. 2003 - 1: 229-238

\title{
KÖNYVJELZÖ
}

\section{BIHARI TÉRSÉG}

Szerk.: Baranyi Béla

(CSISZÉR BT-CEBA KIADÓ, Debrecen, 2002. 246 o.)

\section{SZABÓ GYULA}

A kötet a Ceba Kiado Magyarország kisrégióit bemutató sorozatának legújabb, egyben a Hajdú-Bihar megye kistérségeit tartalmasan és látványosan reprezentáló megyesorozat utolsó darabja, amely az MTA RKK Debreceni Osztálya kutatóinak közreműködésével, Baranyi Béla szerkesztésében, valamint a Csiszér Bt. gondos kiadói közremủködésével készülhetett el igen magas színvonalon és vonzó formában. Elterjedt nézet, hogy a regionális alapon szervezödött kistérségek nálunk is fontos szerepet játszhatnak a helyi társadalom életének megszervezésében, a regionális tudat és szemlélet kialakításában, formálásában. Az európai példák ebbe az irányba mutatnak, és remélhetjük, hogy idővel hazánkban is hasonló szerepet tölthetnek be ezek a területi szerveződések. Ma ez sajnos inkább csak a kívánságok szintjén fogalmazódik meg, ám éppen az ehhez hasonló kötetek segíthetnek az elörelépésben: nemcsak a Kelet-Magyarországot utazási célként kiválasztó turisták, üzletemberek forgathatják haszonnal a könyvet, de a bihari kisrégió lakói is. Feltételezhetjük ugyanis, hogy a leírt természeti szépségek, történelmi nevezetességek egy része még az ő számukra is újdonságot jelent majd, tágabb lakókörnyezetük megismerése pedig a helyi identitás erösítését hozhatja magával.

A könyvsorozat hányatatott sorsa valószínüleg nem ismeretlen azok előtt, akik érdeklödnek a regionális tudományok iránt, és figyelemmel kísérik az ezzel kapcsolatos kiadványokat. A sorozat megjelentetése körüli problémákról jelen folyóirat oldalain is bóvebben megemlékezett néhány hónappal ezelótt Balcsók István a Debreceni kistérségről megjelent kötetről irott ismertetőjében. Ugyanő ezúttal már mint szerző szerepel a Bihari kistérségről szóló könyvben, az ő munkáját dicséri a könyv elsö, a térséget általánosan bemutató fejezete.

Bárki is írjon Bihar történetéról vagy jelenéról, nem kerủlheti el néhány körülmény leírását. A legfontosabb ezek közül Bihar „csonka” voltának hangsúlyozása, ami meghatározza a természetföldrajzi és történelmi táj, az egykori Biharország szerves részét alkotó, s Trianon következményeit mindmáig magán viselö térség modern kori történetét. A történelmi Magyarország egyik legnagyobb megyéjéböl vált elöbb csonka megyévé, majd lett újabb „területvesztéssel” Hajdú-Bihar megye egyik részévé. A kötet is ennek az âllapotnak a bemutatásával kezdődik, ami természetes, a könyvet végigolvasva a laikus érdeklődő számára is világossá válhat, hogy 
Tér és Társadalom 17. évf. 2003/1. 229-232. p.

ez a tény mennyire meghatározó volt - és az még ma is - az érintett települések számára. Ezzel függ össze, és bár sokat idézett, mégis kihagyhatatlan egy ilyen mủből Mendöl Tibor, Magyarország neves geográfusának leírása a helyzetről. Az általa írt néhány sor is olyan remekuil foglalja össze mindazt, amit a trianoni határok a bihari térség számára jelentettek, hogy itt is érdemes felidézni: „Csonka-Biharban minden csonka. Nincsen egyetlen kerekded, határain belül záródó tájegysége, csupa határain túl kiegészülö tájdarabokból rakódik össze mozaikszerüen. Semmi sem kezdödik, vagy fejezödik be a területén, minden csak átfut rajta..."

A „csonkítást” a kötet szerzői sem kerülhették el, hiszen az 1920 óta Magyarországhoz tartozó Bihart sem mutathatták meg teljes egészében ebben a kötetben. Az ekkor létrejött Csonka-Bihar vármegye 60 települése is csak a II. világháborút követö közigazgatási reformig maradt összefüggö és önálló területi egység. Az 1949-50-es reformokkal 12 település, Sarkad és térsége a szomszédos Békés megyéhez került, a többi pedig az egykori Hajdú vármegyével alkotja ma is Hajdú-Bihar megyét. De ez sem minden, hiszen a kistérségi határok meghúzásánál sem vették teljesen figyelembe a tájhatárokat, olyan nagy múltú bihari telepiilések például, mint Nagyrábé, Bihartorda, Biharnagybajom és Bihardancsháza ma a szomszédos Sárréthez, illetöleg a Püspökladányi tervezési-stratégiai (KSH) kistérséghez tartoznak. A könyvsorozat logikájának megfelelően ezért ezeket nem itt, hanem a Sárrétet bemutató kötetben találhatjuk meg.

Visszatérve az említett általános bemutatóhoz, ennek feladata, hogy az egyes település-leírások előtt átfogó képet adjon a térségröl, megalapozza mindazt a tényanyagot, amit a későbbi fejezetek tartalmaznak. A feladat különösen nehéz, mivel olyan széles látókört igényel, mint kevés más tudományos munka. A szerzönek nem egy szúkebb szakterület kérdéseiről kell összegzést adnia, hanem számos, egymástól néha jelentősen különbözỏ tudományág ismereteit kell összegyüjtenie, ráadásul a terjedelmi korlátok miatt röviden, mégis úgy, hogy a szöveg ne veszítse el koherenciáját. Nehéz döntés, hogy mi maradjon ki, nagyrészt a fejezet írójának és a kötet szerkesztőjének tapasztalatán múlik, mit tart fontosnak megemlíteni. Adott esetben a közigazgatási határok változásának már említett bemutatása mellett a bihari térség elmaradottságának okaiként felhozható legfontosabb tényezök kerültek ide első helyen. A periférikus helyzet és az elvágott közlekedési kapcsolatok okozta hátrányos helyzet ábrázolása indítja a kistérség megismertetését. Viszonylag kisebb súlyt kapott Bihar történelme és néprajzi értékei, viszont igen alapos a bihari tájat, a természeti környezetet bemutató rész.

A következő, a településeket bemutató fejezetek egységes mintát követnek, amikor sorra veszik a földrajzi, természeti adottságokat, a település rövid történetét, a kulturális élet, oktatás, vallás kérdéseit, majd a gazdaság állapotát, végül kitérnek a meglátogatható múemlékekre, idegenforgalmi látványosságokra. Ezek az adatok minden valószínủség szerint néhány esetben a régió ismerői számára is tartogathatnak meglepetéseket, kevésbé a gazdaság vagy az infrastruktúra teriuletén (itt sajnos semmi meglepetésre nem számíthatunk, a kelet-magyarországi, agrár-jellegủ településekről kialakult kép nagyjából fedi a valóságot), inkább a történelmi vagy a 
Tér és Társadalom 17. évf. 2003/1. 229-238. p.

kulturális kérdésekben. Jó példa erre Ártánd esete, amely az ország egyik legrégibb írott forrásban említett települése, neve a második magyar nyelvemlék, a Garamszentbenedeki Apátság 1075-ben kiadott alapítólevelében is felbukkan. Ez a tény annak ellenére, hogy jogos büszkeséggel töltheti el az ott élöket, szinte teljesen ismeretlen, még a környéken élő́k számára is.

Természetesen az a fajta sokoldalúság, amelyre az előbbiekben az általános bemutatás szerzője kapcsán utaltam, nem csak rá, de az összes többi szerzöre, a településleírások elkészítöire is igaz. A szerzöknek egyszerre kellett történésznek, geográfusnak, demográfusnak, idegenforgalmi szakembernek és még egy sor más tudományág képviselöjének lenniük. A kötetet jegyzö mindhárom szerző, Baranyi Béla, Balcsók István és Dancs László sikerrel oldotta meg a lehetetlennek tủnő feladatot: átlagosan 3-4 oldalba belesűríteni mindazt, amit egy településröl tudni kell. Természetes, hogy a terjedelmi korlátok miatt az egyes településeket bemutató fejezetek nagyrészt adatok felsorolására szorítkozhatnak csupán. A szerzök azonban nem elégedtek meg ennyivel, a kötetben szereplö 31 település mindegyikét igyekeztek valamiféle egyéniséggel felruházni bemutatása során, hogy az olvasó a sok statisztikai adat ellenére hosszabb távon is maradandó emlékekkel gazdagodjon. Az egyes fejezetek címei jol kifejezik ezt a törekvést, mindhárman olyan címeket igyekeztek adni, amelyek elolvasás után nyomot hagynak az olvasóban, a település egy olyan jellegzetességét ragadják meg, amely különösen érdemes a figyelemre.

Ha valaki több ilyen fejezetet végigolvas, mindenképpen kialakul benne egyfajta kép a kistérség egészéröl is. A legfontosabb tanulság az olvasás során az volt, hogy a terület rendkívüli mértékben hátrányos helyzetben van az élet szinte minden területén. A településeket bemutató fejezetek csak megerösítik az általános bevezetö kapcsán leírtakat a szétszakított egykori Biharról, a periférikus helyzetrỏl. A szerzők írásaiból meglehetősen sötét kép rajzolódik ki, elsősorban természetesen a gazdaság és a foglalkoztatottság területén. Ez magától értetödően nem a szerzök hibájából történt, a kistérség adottságai sajnos ilyenek. Kivétel nélkül minden településre igaz, hogy a mezőgazdaság meghatározó szerepet játszik gazdaságában, látványos fordulat ennek megfelelỏen a foglalkoztatottságban vagy az önkormányzatok adóbevételeinek tekintetében reálisan nem várható. Ha a leírásokban különbségeket, valamiféle szintkülönbséget igyekeztek keresni a települések között, akkor nem iparosodott és agrár-jellegü, pénzüigyileg jobb és rosszabb helyzetben lévő falvakat, városokat tudtak megkülönböztetni, hanem hátrányos és halmozottan hátrányos helyzetủeket.

A település-leírásokat követi a kötetben az idegenforgalmi kalauz, ami Dancs László munkáját dicséri. Bihar hazánk azon tájai közé tartozik, melyeket a turisták ritkán „találnak meg”, nem a légnépszerübb célpontok egyike. Az okokat feltehetöen több területen kell keresni, de ezek között mindenképpen szerepel az információk hiánya. A sorozat egyik, talán legfontosabb célja, hogy ezt az információhiányt csökkentse. A feladatot a szerző remekül oldja meg: számos, föképp történelmi, épitészeti és néprajzi értékeket felvonultató települést mutat be anélkül, hogy a látnivalók felsorolása unalmassá válna. Nem hallgatja el azonban azt sem, ami az 
információhiányhoz hasonlóan akadályozza a turisták áradatának megindulását, vagyis, hogy a térségben szinte egyáltalán nem lehet szálláshelyeket találni.

Ha a könyv hiányosságaira is ki szeretnénk térni, mindenképpen meg kell említeni, hogy a sorozatnak ebben a részében az egyes fejezetek angol nyelvủ összefoglalói mellól hiányoznak a német nyelvủek. Az angol nyelv elsődleges szerepe a nemzetközi kapcsolatokban ugyan nem tagadható, mégis hiányérzetủnk lehet ezzel kapcsolatban. Ha elfogadjuk, hogy a kötet jelentös részben idegenforgalmi célokat szolgál, a térség hatékonyabb megismertetését határainkon belül és kívül, nem lett volna szabad kihagyni ezt a lehetöséget, hiszen a régióba látogató külföldiek között jelentős számban találhatunk német anyanyelvüeket.

A kötetet a térség hírneves szülötteiröl és kiemelkedő egyéniségeiröł a kitűnő irodalomtörténész, lapszerkesztö, Bakó Endre által készített lexikonszerü „Kikicsoda"-összeállítás, valamint válogatott bibliográfia teszi teljessé.

Végül, de egyáltalán nem utolsó sorban kell megemlíteni a kötetben nagy számban szereplö fényképeket, Vencsellei István lírai hatású munkáit, a „vizuális költészet” remekeit. Az elismert fotómúvész nem egyszerüen illusztrációkat készített az írásokhoz, annál jóval többröl van szó. A képek fontos kiegészítői a kötetnek, a könyvet csupán átlapozva is azonnal megragadják az ember figyelmét, mint például a kötet borítóján látható, a herpályi templomot ábrázoló felvétel. A gondosan szerkesztett, nyomdatechnikailag egyébként is magas színvonalú könyvben az illusztrációk nagyban hozzájárulnak ahhoz, hogy a kötet elérje célját: mindenki számára érthető módon, mégis tudományos igényességgel mutassa be a többség által kevéssé ismert, és nem eléggé értékelt bihari tájat. 